Article

\title{
Forest Dependent Indigenous Communities' Perception and Adaptation to Climate Change through Local Knowledge in the Protected Area-A Bangladesh Case Study
}

\author{
Md. Habibur Rahman * and Khurshed Alam \\ Bangladesh Institute of Social Research (BISR) Trust, House no. 6/14, Block no. A, Lalmatia, Dhaka 1207, \\ Bangladesh; bisr@agnionline.com \\ * Correspondence: habibmdr@gmail.com; Tel.: +88-028-100-658
}

Academic Editors: Angelika Ploeger, Sisira S. Withanachchi and Engin Koncagul

Received: 30 November 2015; Accepted: 15 February 2016; Published: 19 February 2016

\begin{abstract}
Forest-dependent indigenous communities rely on natural resources for their livelihoods, but those are currently under threat due to many factors, including the adverse impact of climate change. The present study looks into climate change-related perception and adaptation strategies of three forest-dependent indigenous communities, namely, Khasia, Tripura and Garo in the Lawachara National Park of Northeastern Bangladesh. Household surveys, focus group discussions, key informant interviews, and observation methods were used to unveil the climatic events, impacts and related adaptations. The events include the change in temperature and rainfall patterns, landslide, soil erosion and flash flood, heavy cold and fog, and natural calamities. Moreover, livelihood problems emanating from these events are the drying up of streams and wells, irregular rainfall, increased dieback and mortality of seedlings, pests, diseases, and the attack of crops by wild animals. Likewise, the reduction of soil moisture content, growing season and crop productivity, landslides, damage of roads and culverts, and increased human diseases are common. This study recognized 29 adaptation strategies and divided them into six management categories, drawing on their local knowledge of the natural resources and other technologies. The study reveals that, although adaptation strategies through land use and land cover changes are not enough to sustain their livelihoods, the tactics help them to reduce the risk of, and increase food security and community resilience against, climate change.
\end{abstract}

Keywords: agroforestry; climate change perception; climatic risk; management category; Khasia; Tripura and Garo; Lawachara National Park

\section{Introduction}

Climate change has become a much-talked-about issue nowadays throughout the world, as it is believed to be one of the biggest threats to the planet Earth. Bangladesh is no exception in the broader context of climate change, which casts an ominous shadow on the country because of its lowly elevated coastal zone, high level of population density, widespread poverty, and an overwhelming dependence on nature. Against this backdrop, local practices and local knowledge need to be given highest priority to deal with the adverse effects of climate change. At the outset, a fresh look into the possible impacts of climate change on human livelihoods needs to be recapitulated. Threats associated with climate change have already affected many arenas pertaining to human livelihood like agriculture, forest, fisheries, biodiversity, food security and health [1]. Least developed countries (LDCs) are reported to suffer more from the negative impacts of climate change due to their heavy dependence on natural 
resources and agriculture [2]. The most possible impacts of climate change in these countries are rising temperature, high or low rainfall, continuous natural disasters and flooding, frequent and prolonged droughts, and sea level rise [3].

Following that trend, these days, extreme climate events such as drought, change in rainfall patterns, tropical cyclones and storm surges are affecting Bangladesh to a considerable extent [4]. If the trend continues, it will be instrumental to assume multiple detrimental effects on all of the development sectors, making it imperative to adapt the local and/or indigenous knowledge-based policies to resolve the problem to a considerable extent. A few studies on local and indigenous knowledge-based adaptation to climate change have been pursued in Bangladesh, such as Ahmed [5], Islam and Atkins [6], Mahmood et al. [7], Alam [8], and Anik and Khan [9]. Those studies have found that such knowledge is practiced from generation to generation, and assists community in making informed decisions about how to respond to environmental changes and about how to adapt and improve the situation. Although the local knowledge is time-, place- and culture-specific it makes individual and community adaptive as well as increases resilience capacity towards climate variability and change.

With all these alarming trends, recently there has been a growing concern over forest resources, as it has taken centre stage for global mitigation and adaptation measures in addressing the climate change issue [10]. Over the past half-century, climate changes have affected many aspects of forest ecosystems, including tree growth and dieback, invasion of invasive species, species distributions and migrations, changes in seasonal patterns in ecosystem processes, demographics, and even species extinctions [1,11,12]. Out of more than 1.6 billion people depending on forest resources (about 350 million people are considered highly forest-dependent), 60 million indigenous people are totally dependent on forests, and 1200 million are dependent on agroforestry practices [13]. Climate change is causing a negative impact on their farming systems-visibly or invisibly-that are likely to deteriorate further in the near future. Therefore, the assessment of the likely impacts of climate change on forests and forest-dependent people and their vulnerabilities are thus important for enhancing climate change adaptation.

Globally, indigenous people occupy only $4 \%$ of the world's population, but they manage $11 \%$ of the total forestlands. They maintain $80 \%$ of the world's biodiversity and are located in or adjacent to $85 \%$ of the world's protected areas [14]. In doing so, indigenous community lands sequestrate hundreds of gigatons of carbon, which is an effort to mitigate climate change. However, indigenous communities have scanty resources and few options to adapt (financially, technically and socially) by themselves where most adaptive strategies constitute local knowledge. Such local knowledge, as highlighted in this paper, have a significant role to play in addressing climate change challenges and may prove critical to grasp the potential of certain adaptation strategies that are cost-effective, participatory and sustainable. However, research related to adaptation strategies with local/indigenous knowledge use is still lacking. Studies conducted by Spittlehouse and Stewart [15], Chaudhary and Bawa [16], Chaudhary et al. [17], Fardous [18], Kebebew and Urgessa [19], Boon and Ahenkan [20], Parrotta and Agnoletti [21], Couzin [22] and Vedwan and Rhoades [23] are among the noteworthy that deal with the application of local and/or traditional knowledge in adapting to climate change in the forestry sector. In addition, the United Nations University's Traditional Knowledge Initiative (UNU-TKI) and the Intergovernmental Panel on Climate Change (IPCC) have been partnered and are working to address gaps in local knowledge and climate change adaptation and mitigation, and to promote respect for local knowledge and the role of indigenous peoples in policy development [24].

Bangladesh, a tropical climate country, has 2.53 million ha of forest lands representing about $17.5 \%$ of the country's area. Almost all of the indigenous communities in the country are living within the forest boundary and are heavily dependent on the forest resources for their subsistence and livelihoods [25,26]. These communities used to manage different types of agroforestry systems, namely, agrosilvipastoral systems, agrisilvicultural systems and woodlot plantations for decades [27]. They also have developed indigenous knowledge systems of their own by practicing the special type of utilization pattern of forest produces. However, since the last decade, these communities 
have been facing challenges of intensified management over its traditional agroforestry management systems [27-29] due to climate variability and change, their dependence on agroforestry products and forest resources, as well as overpopulation in a limited forestland.

Four indigenous communities, namely, Khasia, Tripura, Garo and Manipuri are living in and around Lawachara National Park (LNP) located in Northeastern Bangladesh, each having a different culture, ecosystem and livelihood patterns. Each community has been engaged in different types of agroforestry systems for generations, such as betel leaf (Piper betle)-based agroforestry, lemon (Citrus limon)-based agroforestry, pineapple (Ananas comosus)-based agroforestry, mixed culture agroforestry, and agriculture farming. They depend on forest resources for their livelihood, and their farming systems are severely affected by climate change. Betel leaf-based agroforestry by the Khasia community has been practiced in the forested land since 1914, which was leased out to the community by the Forest Department (FD) on a renewable basis for 99 years to ensure better management of the forest resources and to reduce illegal encroachment [30]. In exchange, they supply labor when and where needed for the FD plantations work. However, the condition of the forests did not improve due to illegal forest product extraction and the continuation of shifting cultivation [31]. On the other hand, the FD leased the forestland to the chief of the Khasia community called "Montri" or "Headman" who deals with the FD, and leases the forestland to his community members; in return, they collect revenue at the end of the year. Each household gets 1.5-2.0 acres of land. Contrary to that, land that belongs to the Tripura community has been owned by them for the last 300 years by what might be called customary rights in land that they enjoy. Since the nature and control over land are not the focus of this study, a detailed investigation has not been made here.

The Khasia hills and the Shillong of the Meghalaya State (India) are the area where the Khasia indigenous community mainly settled [32]. The Tripura hilly people in Bangladesh migrated from the Tripura State of India, but both countries have a common history, culture, tradition and life style. On the other hand, the Garos are one of the well-known indigenous communities of the Indian subcontinent. Most of them are living in Northeastern India, mainly in the Garo hills [33]. Nowadays, about one-fifth of the total population of the Garos lives in Bangladesh [33]. They have their own local knowledge to manage natural resources for their livelihoods [27]. The main income of Khasia comes from betel leaf-based agroforestry, followed by paddy cultivation and firewood collection. About 70\% of Tripura households depend on the agroforestry, and the remaining 30\% are day laborers. The Khasia women mainly sort betel leaves, while Tripura women weave cloths and do household work and sometimes they work in the agroforestry farms. Garo community is involved in agriculture, but they are mainly serving as tea laborer for several generations [34]. Other studies found that the agroforestry system provides sustainable livelihood support to the forest-dependent indigenous communities in LNP [30,35].

Agroforestry can be seen as a form of sustainable intensification of agro-ecosystems, where yields get increased without adverse environmental impact and without the cultivation of more land [36,37]. Though agroforestry shows promise for co-delivery of adaptation (high biodiversity and resulting ecosystem services by diversified farming) to, and mitigation (carbon sequestration) of, climate change [38-40], there is a lack of hard evidence justifying this, particularly in the context of a developing country like Bangladesh. It has therefore become imperative to carry out an in-depth study on this. In the present study, the following questions are addressed: Which impacts of climate change are significant in the study area? Which ways are the indigenous communities changing their behavior to adapt these impacts? This article therefore aims to: (i) identify the impacts of climate change on forest and indigenous communities' livelihoods in and around the LNP; (ii) explore the perception and knowledge of indigenous communities towards climate change; and (iii) investigate and identify the adaptation measures that are practiced meaningfully by the indigenous communities to strengthen community resilience. The outcomes of this study might be helpful for the forest managers, policymakers, researchers, non-governmental organizations (NGOs) and development partners dealing with climate change impacts and community-based adaptation related to forest areas. 


\section{Materials and Methods}

\subsection{Profile of the Study Area}

The Lawachara National Park, with a total area of 1250 ha, is located at Kamalganj Upazila (sub-district) in Moulavibazar District and a part of the West Bhanugach Reserved Forest. Geographically, it lies between $24^{\circ} 30^{\prime}-24^{\circ} 32^{\prime} \mathrm{N}$ and $91^{\circ} 37^{\prime}-91^{\circ} 47^{\prime} \mathrm{E}$ (Figure 1 ). The area is undulated with slopes and hillocks, locally called tilla, ranging from 10-50 m scattered in the forest. Numerous streams flow through the forest. Soil organic matter and fertility levels are generally low, and texture is generally sandy loam or silty loam. The vegetation of the area consists of mixed semi-evergreen old secondary forest with a 528.5 ha tree density. The canopy height varies from $10 \mathrm{~m}$ to $30 \mathrm{~m}$. Almost all original forest cover has been removed or substantially altered and thus has turned into a secondary forest, which has developed a multistoried structure and dense forest, looking like virgin natural forest. Tea gardens, rubber gardens, short and long rotation plantations, agroforestry and paddy fields, etc. surround the park [41].

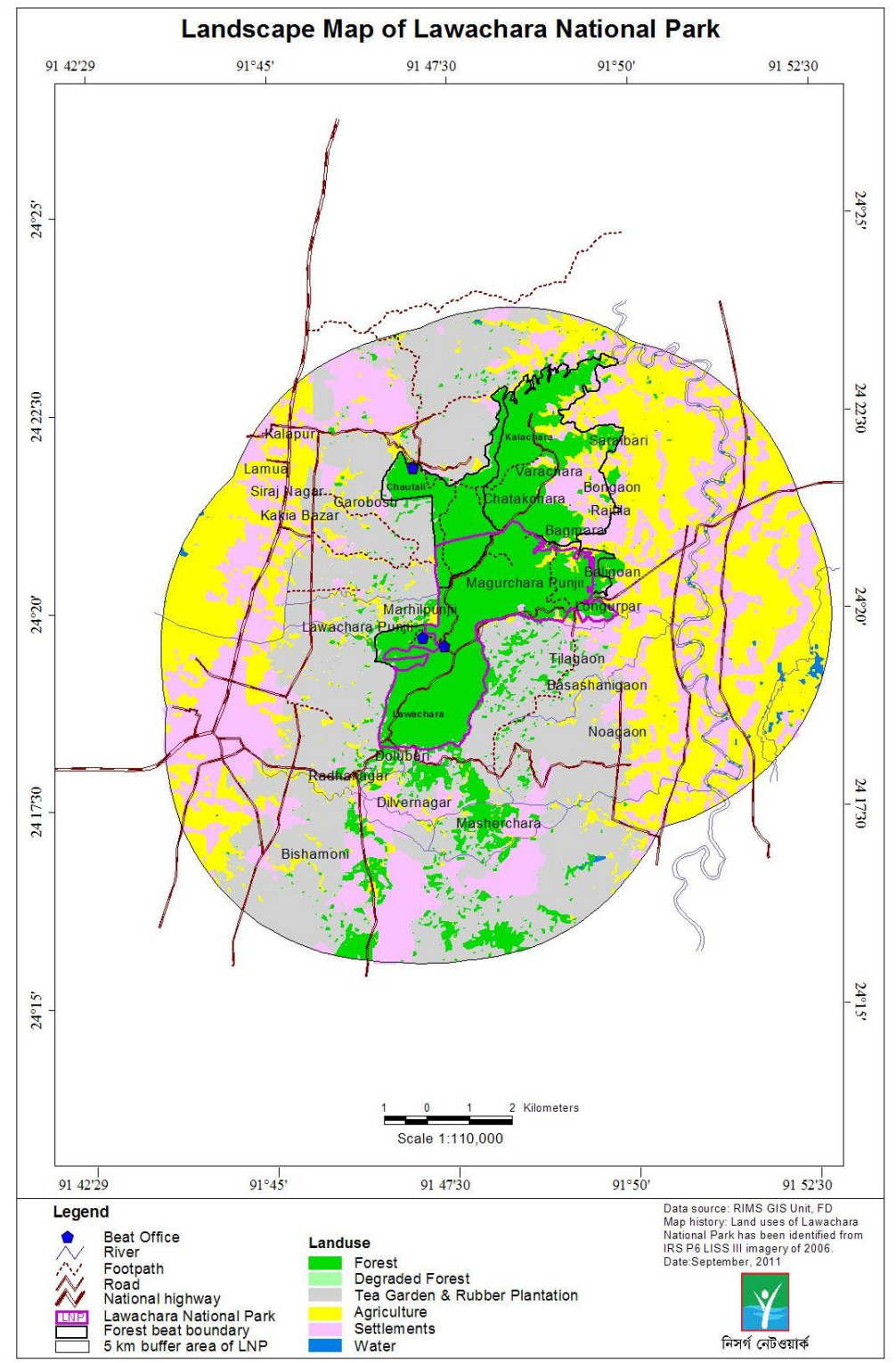

Figure 1. Landscape map of Lawachara National Park. 
LNP consists of 460 species, of which 167 are floral and 293 are faunal (246 bird species, 20 mammal species, 17 insect species, 6 reptile species and 4 amphibian species) [41,42]. The LNP is also one of the last habitats of an endangered, non-human primate Hollock Gibbon (Hoolock hoolock) [43].

The average temperature of the park is $26.8^{\circ} \mathrm{C}$; May and October are the hottest months $\left(36.1{ }^{\circ} \mathrm{C}\right)$ and February is the coldest $\left(10^{\circ} \mathrm{C}\right)$. This area is one of the wettest in the country with an annual average rainfall of $4200 \mathrm{~mm}$, with maximum fall occurring from June to September from southwest monsoon. The humidity is high in the park (70\%-85\%) throughout the year, with the monthly average ranging from $74 \%$ in March to $89 \%$ in July. Pre-monsoon nor westerly and cyclonic storms are accompanied by high-speed winds and rains, which do considerable damage to property and trees [41]. Furthermore, the LNP is the most attractive ecotourism destination to country and abroad due to its aesthetic beauty, dense mixed forests, undulated natural slopes and hillock-based landscape, indigenous community diversity and their historical and cultural values, tea gardens and coffee plantations.

Presently, the LNP forest management has undergone collaborative forest management with active involvement with the local stakeholders. Since 2013, Winrock International through USAID is implementing a project entitled "Climate Resilient Ecosystem and Livelihood (CREL, 2013-2017)" in partnership with Bangladesh FD. The aim of this project is to better manage and conserve Bangladesh's natural resources and biodiversity by keeping pace with climate change through the involvement of local stakeholders. Before that, Nishorgo Support Project (NSP, 2004-2009) and Integrated Protected Area Co-management Project (IPAC, 2009-2013) were implemented with the technical assistance of International Resources Group (USA) and East-West Center of University of Hawaii, aiming to protect and conserve the forest biodiversity and sustainable use of forest resources. End results of these two projects include reduction of forest dependency by undertaking alternative income-generating (AIG) activities; decreased illicit felling; decreased mature timber tree but increased species richness and abundance inside the core zone; improved quality of forest resources; increased tourists, and an increased amount of participation in decision-making from the community and the poor. A few representatives from the indigenous communities are there in the Co-Management Committee (CMC) and help to take into account their indigenous or traditional knowledge during decision-making for forest management.

About 30 villages (approximately 4000 households) are situated in and around the LNP, where villagers are involved in different forest practices, labor intensive works, small businesses, eco-tour guide and other services. Of the forest practices, the Khasia (100\%) and Garo (few households) indigenous communities practice betel leaf-based agroforestry system (totalling 130 ha of natural forest used for betel leaf cultivation, rotation is $>8$ years). Pineapple-based agroforestry system (rotation 4-5 years), lemon-based agroforestry system (>15 years rotation) and mixed culture agroforestry systems have been managed by the Tripura community.

Six tea gardens are located at the border of southeast, on the south and east sides, and at one coffee plantation on the west side of the forest, which provides shelter to a large number of their laborers. These communities illegally enjoy different levels (from high to low) of access to forest outputs through cutting the forest plants in addition to hunting wildlife. Studies have found that the Garo community has a tendency to collect more tree branches, saplings and leaves, as their homestead garden is not rich in tree species. The Khasia community collects more non-timber forest products (NTFPs) and house building materials. Although they have rich homestead gardens, their tendency is to keep their garden untouched to protect it from wind and landslide. The Tripura community collects mainly bamboo and house building materials to make bamboo-made handicrafts for their own use and for selling for subsistence.

\subsection{Survey Methods}

At the outset, a reconnaissance survey was carried out to get a rudimentary idea about the indigenous communities' locality, their livelihood, and their farming system. Necessary permission for interviews was obtained from the FD, and the Montrias community, without the Montri's consent, 
did not want to talk to outsiders. A list of all household heads was collected from the FD as well as from the Montri. Household surveys (HHs), key informant interviews (KIIs), focus group discussions (FGDs), and field observations were made to identify the climate-related risks faced by the communities, and their corresponding adaptation strategies. Some other tools, such as problem matrix and problem scoring, were also used to prioritize the risks after identification.

\subsubsection{Selection of the Study Villages}

Out of the four indigenous communities, three communities (i.e., Khasia, Tripura and Garo) spread out over four villages were selected purposively to conduct the survey, keeping conformity with the objectives of the study (Table 1). Two villages, namely, Lawachara Punji and Magurchara Punji (major forest-dependence and completely inscribed in the park) are allotted to the Khasia community; the Tripura community lives in the Dolubarivillage (major forest-dependence), and the Garo community in the Gilachara village (medium forest-dependence). However, the Monipuri community was kept out of this study due to their no or lesser dependence on the forest.

Table 1. Sample distribution over the surveyed villages.

\begin{tabular}{|c|c|c|c|c|c|}
\hline Village & Community & $\begin{array}{l}\text { Population } \\
\text { Size (HHs) }\end{array}$ & $\begin{array}{l}\text { Location and } \\
\text { Distance }\end{array}$ & $\begin{array}{l}\text { Forest } \\
\text { Dependency }\end{array}$ & Forest Practices \\
\hline Lawachara Punji & Khasia & $23(n=13)$ & Inside (0 km) & Major & $\begin{array}{l}\text { Practice betel leaf-based agroforestry, } \\
\text { collect NTFPs, house building materials, } \\
\text { fruit and other NTFPs }\end{array}$ \\
\hline MagurcharaPunji & Khasia & $41(n=20)$ & Inside $(0 \mathrm{~km})$ & Major & $\begin{array}{l}\text { Practice betel leaf-based agroforestry, } \\
\text { collect NTFPs, house building materials, } \\
\text { fruit and other NTFPs }\end{array}$ \\
\hline Dolubari & Tripura & $75(n=40)$ & $\begin{array}{l}\text { Adjacent } \\
(0.5 \mathrm{~km})\end{array}$ & Major & $\begin{array}{l}\text { Practice lemon and pineapple-based } \\
\text { agroforestry, mixed culture agroforestry, } \\
\text { collect NTFPs, house building materials, } \\
\text { fruit and other NTFPs }\end{array}$ \\
\hline Gilachara & Garo & $40(n=20)$ & $\begin{array}{l}\text { Northwest } \\
\text { corner }(1.5 \mathrm{~km})\end{array}$ & Medium & $\begin{array}{l}\text { Practice betel leaf-based agroforestry, } \\
\text { collect NTFPs }\end{array}$ \\
\hline
\end{tabular}

\subsubsection{Field Techniques and Data Collection}

Primary information was collected using a semi-structured questionnaire and checklists after pre-testing for intelligibility and appropriateness. FGDs and KIIs were carried out with the local elites, management representatives, and the representatives of the local NGOs to gather insightful information about the locality regarding climatic variability and their adaptation measures. Several informal discussions were also pursued at the local tea stalls, where locals gather spontaneously in the afternoon after their daily works. No formal invitation to the locals was made for participating at the discussions.

In the case of the HH survey, the study purposively aimed to interview the head (either male or female) of targeted households at daytime, where old-age members of the $\mathrm{HH}$ were also interviewed by following "the Age-Order Procedure" in case the head was absence. Initially, the study aimed to cover half of the total community HHs and finally achieved the targeted HHs (Khasia 51.6\%, Tripura $53.3 \%$ and Garo 50\%) for interview (Table 1). As the total population is small, we purposively selected and interviewed the odd $\mathrm{HH}$ numbers from the $\mathrm{HH}$ lists (for example 1, 3, 5, etc.) as a sample $\mathrm{HH}$ for the study instead of simple random sampling. Finally, among the surveyed respondents, $71 \%$ were found male and the remaining $29 \%$ were female.

HHs survey and KIIs' findings were validated through the FGDs. A total of 93 randomly selected HHs were surveyed (Lawachara Punji 23 ( $n=13)$, Magurchara Punji $41(n=20)$, Dolubari $75(n=40)$ and Gilachara $40(n=20)$ ) (see Table 1$)$. In addition, four other KIIs and FGDs (one from each village) were conducted from April to August 2012. Available weather data, i.e., air temperature data of the last 31 years (1980 to 2011), and rainfall data of 29 years (1982 to 2011) had been collected from the local Sreemangal Meteorological Station and Bangladesh Bureau of Statistics. 
The following questions were asked to the community people during household surveys, KIIs and FGDs but not limited to: forest dependency, knowledge and perception about climate change, understanding the changing patterns of temperature, rainfall and natural calamities during the last 20 years, observed climatic risks including frequency and intensity, effect on production of agriculture and agroforestry crops, indigenous adaptation strategies with the changing environment, effect on community livelihoods and forest ecosystem, and attitudes toward forest conservation, support received from external agencies regarding climate change, etc. (see detail in Appendix).

\subsubsection{Data Analysis}

For simplicity, the study considers four adaptation strategies followed by the indigenous communities: (i) individual adaptation driven by local knowledge; (ii) individual adaptation facilitated by government and non-government organizations; (iii) community-based adaptation driven by local knowledge; and (iv) community-based adaptation facilitated by government and non-government organizations. Moreover, listed adaptation strategies were classified into three: material adaptation, methodical adaptation and mixed adaptation. Furthermore, adaptation strategies were categorized into different management categories such as water management, soil management, crop management, energy management, income management and production management.

Responses on observed climatic risks were collected through individual survey. Three options were provided to respondents which include: "Yes, have experienced," "No, haven't experienced," and "No comment." Then, a five-point scale of problem matrix was developed during the FGDs, and points were assigned against each category of problem (i.e., 5-very high, 4-high, 3-moderate, 2-low, and 1-very low). Problem frequency was also listed from the FGDs, and the score was then calculated by multiplying the problem values with problem frequency.

Data were analyzed using SPSS (version 17.0) and presented in cross-tab format using descriptive statistics according to climatic risks. The temperature and rainfall data of the study area have been analyzed to assess the trends of climatic parameters. We analyzed household data by calculating frequencies and percentages of responses for each indicator included in the survey. Chi-squared tests $\left(\chi^{2}\right)$ with a $5 \%$ level of significance were used to examine whether the respondents' responses were uniformly distributed or more oriented towards particular categories of answers. Cramer's phi $\left(\varphi_{\mathrm{c}}\right)$ statistic [44] was used as a measure of strength of association between rows and columns in contingency tables. The $\varphi_{\mathrm{c}}$ statistic is defined as:

$$
\varphi_{\mathrm{c}}=\sqrt{\frac{\chi^{2}}{N(k-1)}}
$$

Where $n$ is the number of observations, and $k$ is the number of rows or columns-the smaller one.

\section{Results}

\subsection{Climate Change Perception of Indigenous Communities}

The indigenous communities were not familiar with the term "climate change." Nevertheless, they noticed the changes in the weather pattern and its consequential impacts. About climate change, respondents gave their views and opinions based on their own understanding. Survey revealed that $14 \%$ respondents were well knowledgeable (Khasia $=61.5 \%$, Tripura $=38.5 \%), 16.1 \%$ had no knowledge $($ Khasia $=20 \%$, Garo $=46.7 \%$, Tripura $=33.3 \%)$, and 38.7\% were not clear $($ Khasia $=22.2 \%$, Garo $=25 \%$, Tripura $=52.8 \%$ ) about the issue of climate change and its consequences (Table 2). The chi-squared statistic is significant $\left(\chi^{2}=20.9, p<0.00\right)$ in association with Cramer's phi statistic $\left(\varphi_{\mathrm{c}}=0.33\right)$, indicating a strong relationship. Here, "well knowledgeable" means experienced and well informed about the issues of extreme weather events and changing climate; "knowledgeable" means informed and aware of the issue; "no knowledge" means no perception; "not clear" means confused about the issue. 
Table 2. Indigenous community perception regarding climate change.

\begin{tabular}{lcccc}
\hline \multirow{2}{*}{ Perception Categories } & \multicolumn{4}{c}{ Indigenous Community Response (\%) } \\
\cline { 2 - 5 } & Total Respondents & Khasia & Garo & Tripura \\
\hline Well knowledgeable & 14.0 & 61.5 & - & 38.5 \\
Knowledgeable & 25.8 & 50.0 & 8.3 & 41.7 \\
Don't have knowledge & 16.1 & 20.0 & 46.7 & 33.3 \\
Not clear & 38.7 & 22.2 & 25.0 & 52.8 \\
No comments & 5.4 & 40.0 & 40.0 & 20.0 \\
\hline
\end{tabular}

Survey revealed that climate change and its impacts pose a series of risks to the forest-dependent indigenous marginal communities. We analyzed the climate risk by the most reliable data sets available on the impacts of extreme weather events (temperature and rainfall) and associated physical and production, i.e., health, forestry, agroforestry and agriculture farming data. To find out the climate risks in LNP, increasing temperature, high rainfall, low rainfall, irregular rainfall (erratic and unpredictable pattern), flash flood, drying up of stream and well, natural calamities such as flash flood, hailstorm, lightning, storm, heavy fog and cold, etc. were considered. We recorded the community response about current and past climatic variability and to the extent that climate change has already left its footprint in the last two decades.

Respondents altogether ranked increasing temperature $\left(75.3 \%, \chi^{2}=10.5, p<0.03, \varphi_{\mathrm{c}}=0.24\right)$ and drying up of streams and wells $\left(72 \%, \chi^{2}=12.3, p<0.02, \varphi_{\mathrm{c}}=0.26\right)$ as the number one among all the climatic risks. Some $67.7 \%\left(\chi^{2}=11.9, p<0.02, \varphi_{c}=0.25\right)$ respondents reported that the rainfall was lowering down as the second most climatic risk for LNP. Irregular rainfall $\left(76.3 \%, \chi^{2}=6.8, p<0.03\right.$, $\left.\varphi_{\mathrm{c}}=0.27\right)$ patterns, natural calamities $\left(61.3 \%, \chi^{2}=1.6, p<0.82, \varphi_{\mathrm{c}}=0.09\right)$, and landslide, soil erosion and flash flood $\left(63.4 \%, \chi^{2}=5.7, p<0.23, \varphi_{c}=0.17\right)$ were altogether ranked as the third most climatic risks for the study area. Maximum intensity score (5) among these risks were increasing temperature, high rainfall and drying up of streams and wells (Table 3). Yearly weather data shows that the temperature is showing erratic pattern and was fluctuating from year 1984 to 2011. The figure also shows an increasing linear trend from the last couple of years (Figure 2). Simultaneously, rainfall data also showed irregular pattern and higher fluctuations from the year of 1982 to 2011 as well as showing a linear trend of lower annual rainfall (Figure 3).

\subsection{Observed Climate Change Impacts and Adaptation Strategies}

The present study identified a total of 29 climate change adaptation strategies practiced by three indigenous communities in different seasons. Among two (6.9\%) were IPA (individual planned adaptation supported by GOs and NGOs), seven (24.1\%) were IALK (individual adaptation through local knowledge), 11 (37.9\%) were CBALK (community-based adaptation through local knowledge), and nine (31\%) were CBPA (community-based planned adaptation supported by GOs and NGOs). Of the adaptation strategies, $20.7 \%$ strategies were practiced by three communities, $51.7 \%$ were practiced by more than one community ( $66.7 \%$ by Khasia and Tripura, $20 \%$ by Tripura and Garo, $13.3 \%$ by Khasia and Garo), and the remaining $27.6 \%$ by a single community ( $50 \%$ by Khasia, $37.5 \%$ by Tripura, $12.5 \%$ by Garo) (Table 4 ).

\subsection{Classification of Adaptation Strategies}

Reported adaptation strategies were classified into three broad categories, namely, materials adaptations (11.1\%), methodical adaptations (37\%) and mixed adaptations (51.9\%). Likewise, the popular adaptation strategies were classified into six categories based on management, namely, crop management (37\%), water management $(11.1 \%)$, soil management $(18.5 \%)$, production management (14.8\%), energy management $(7.4 \%)$ and income management (11.1\%) (Table 5). 
Table 3. Climatic risks observed by three indigenous communities and their ranking matrix.

\begin{tabular}{|c|c|c|c|c|c|c|c|c|c|c|c|c|}
\hline \multirow{2}{*}{ Parameters } & \multirow{2}{*}{ Response } & \multicolumn{3}{|c|}{ Indigenous Community (\%) } & \multirow{2}{*}{ Total (\%) } & \multirow{2}{*}{ Chi-Square $\left(\chi^{2}\right)$} & \multirow{2}{*}{$p$} & \multirow{2}{*}{ Cramer's Phi $\left(\varphi_{c}\right)$} & \multirow{2}{*}{ Frequency/Year } & \multirow{2}{*}{ Intensity $^{a}$} & \multirow{2}{*}{ Score ${ }^{b}$} & \multirow{2}{*}{ Rank } \\
\hline & & Khasia & Garo & Tripura & & & & & & & & \\
\hline \multirow{3}{*}{ Increasing temperature } & Yes & 87.88 & 80 & 62.5 & 75.27 & 10.47 & 0.03 & 0.24 & 3 & 5 & 15 & 1 \\
\hline & No & 9.09 & 15 & 37.5 & 22.58 & & & & & & & \\
\hline & No comments & 3.03 & 5 & 0 & 2.15 & & & & & & & \\
\hline \multirow{3}{*}{ High rainfall } & Yes & 33.33 & 55 & 17.5 & 31.18 & 10.52 & 0.33 & 0.24 & & & & \\
\hline & & 57.58 & 45 & 77.5 & 63.44 & & & & 1 & 5 & 5 & 4 \\
\hline & No comments & 9.09 & 0 & 5 & 5.38 & & & & & & & \\
\hline \multirow{3}{*}{ Low rainfall } & Yes & 63.64 & 95 & 57.5 & 67.74 & 11.95 & 0.02 & 0.25 & 2 & 4 & 8 & 2 \\
\hline & No & 36.36 & 5 & 37.5 & 30.11 & & & & & & & \\
\hline & No comments & 0 & 0 & 5 & 2.15 & & & & & & & \\
\hline \multirow{3}{*}{ Irregular rainfall } & Yes & 78.79 & 95 & 65 & 76.34 & 6.81 & 0.03 & 0.27 & 2 & 3 & 6 & 3 \\
\hline & No & 21.21 & 5 & 35 & 23.66 & & & & & & & \\
\hline & No comments & 0 & 0 & 0 & 0 & & & & & & & \\
\hline \multirow{3}{*}{$\begin{array}{l}\text { Landslide, soil erosion } \\
\text { and flash flood }\end{array}$} & Yes & 54.55 & 55 & 75 & 63.44 & 5.66 & 0.23 & 0.17 & 2 & 3 & 6 & 3 \\
\hline & No & 42.42 & 35 & 20 & 31.18 & & & & & & & \\
\hline & No comments & 3.03 & 10 & 5 & 5.38 & & & & & & & \\
\hline \multirow{3}{*}{$\begin{array}{l}\text { Drying up of stream } \\
\text { and well }\end{array}$} & Yes & 87.88 & 80 & 55 & 72.04 & 12.34 & 0.02 & 0.26 & 3 & 5 & 15 & 1 \\
\hline & No & 9.09 & 15 & 42.5 & 24.73 & & & & & & & \\
\hline & No comments & 3.03 & 5 & 2.5 & 3.23 & & & & & & & \\
\hline \multirow{3}{*}{ Natural calamities } & Yes & 60.61 & 60 & 62.5 & 61.29 & 1.56 & 0.82 & 0.09 & 2 & 3 & 6 & 3 \\
\hline & No & 33.33 & 30 & 35 & 33.33 & & & & & & & \\
\hline & No comments & 6.06 & 10 & 2.5 & 5.38 & & & & & & & \\
\hline \multirow{3}{*}{ Heavy fog and cold } & Yes & 72.73 & 60 & 75 & 70.97 & 3.65 & 0.46 & 0.14 & 1 & 3 & 3 & 5 \\
\hline & No & 24.24 & 25 & 20 & 22.58 & & & & & & & \\
\hline & No comments & 3.03 & 15 & 5 & 6.45 & & & & & & & \\
\hline
\end{tabular}

${ }^{\mathrm{a}}$ Intensity code: 1 -very low or no risk, 2-low risk, 3-medium risk, 4-high risk, 5-very high risk; ${ }^{\mathrm{b}}$ Score: value of intensity $\times$ frequency. 


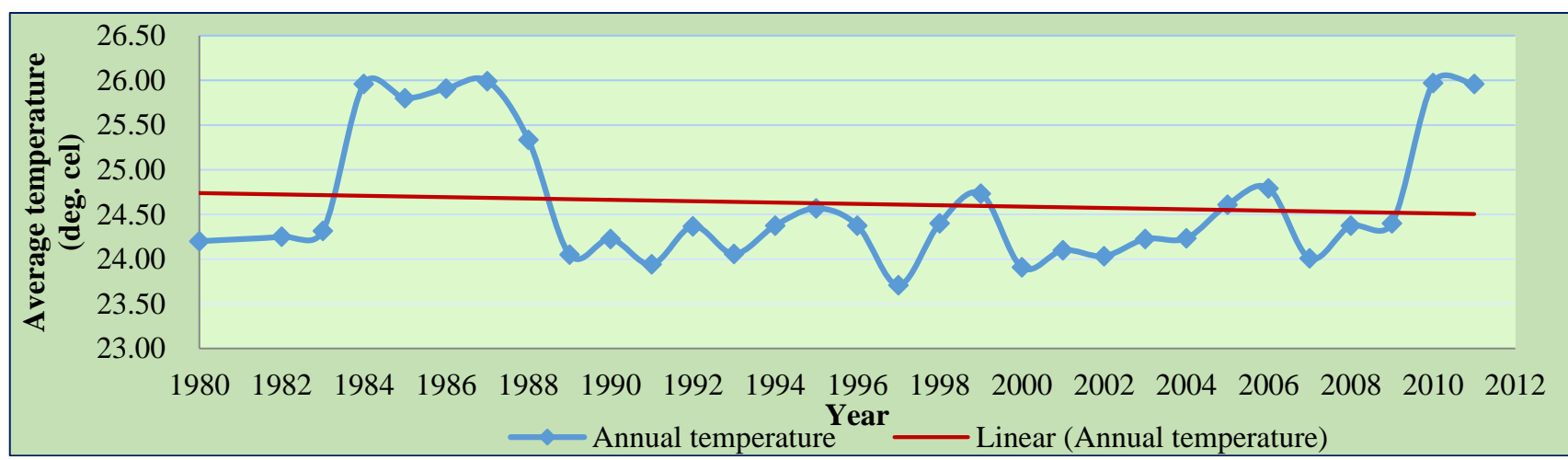

Figure 2. Annual average temperature changing scenario in Lawachara National Park (1980 to 2011).

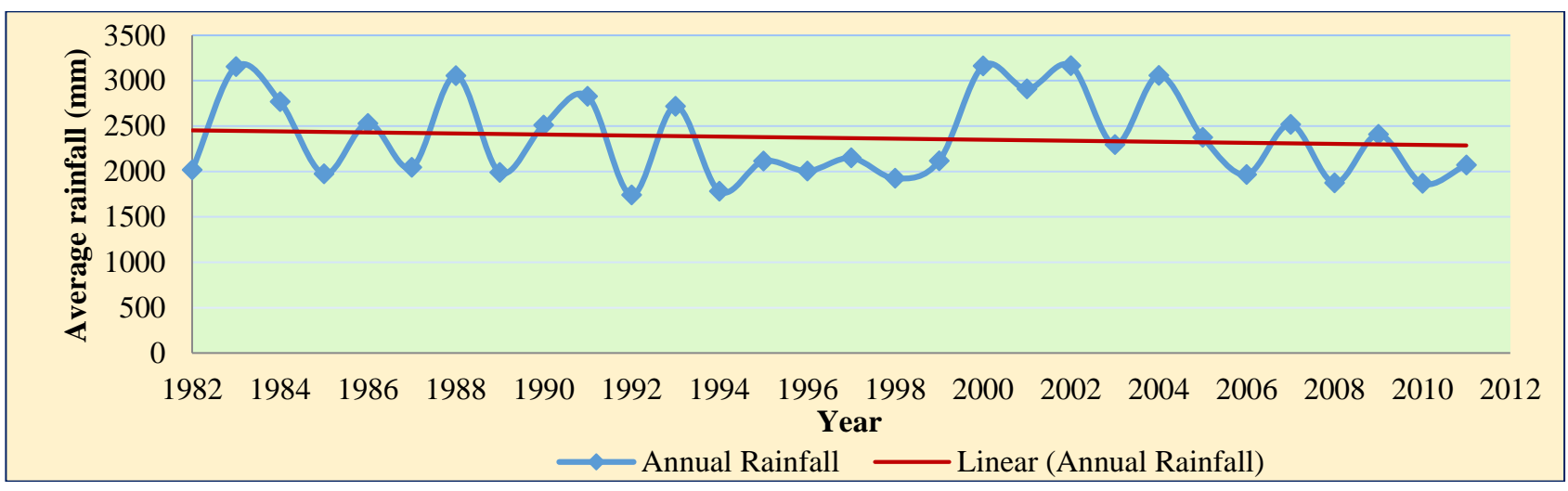

Figure 3. Annual average rainfall scenario in Lawachara National Park (1982 to 2011). 
Table 4. Observed climate change impacts and community-based adaptation strategies followed by the three indigenouscommunities in LNP.

\begin{tabular}{|c|c|c|c|c|c|c|}
\hline \multirow[b]{2}{*}{ Climatic Event } & \multirow{2}{*}{ Observed Climate Change Impact } & \multirow{2}{*}{ Community-Based Adaptation Strategy } & \multicolumn{3}{|c|}{ Community ${ }^{1}$} & \multirow[b]{2}{*}{ Remark $^{2}$} \\
\hline & & & K & $\mathbf{T}$ & G & \\
\hline \multirow{16}{*}{$\begin{array}{l}\text { Rising } \\
\text { temperature } \\
\text { and low rainfall }\end{array}$} & 1. Drying up of forest stream and well & 1. Rainwater harvesting through digging pond and deeper well & $\sqrt{ }$ & (1 & $\sqrt{ }$ & CBPA \\
\hline & $\begin{array}{l}\text { 2. Scarcity of daily working, drinking and } \\
\text { irrigation water }\end{array}$ & 2. Setting water pump and storing water in reservoir & $\sqrt{ }$ & $\sqrt{ }$ & & CBPA \\
\hline & 3. Reducing soil moisture content and fertility & 3. Mulching/covering soil with litter & $\sqrt{ }$ & $\sqrt{ }$ & & IALK \\
\hline & & 4. Using compost and organic fertilizers, lime and oil cake & $\sqrt{ }$ & $\sqrt{ }$ & & CBALK \\
\hline & 4. Dieback and mortality of seedlings & $\begin{array}{l}\text { 5. Planting seedlings with covering and gap filling as well as } \\
\text { regular watering }\end{array}$ & & $\sqrt{ }$ & $\sqrt{ }$ & IALK \\
\hline & 5. Extreme heat & 6. Building resting places alongside road in the Tea Estate & & & $\sqrt{ }$ & CBPA \\
\hline & 6. Drought & $\begin{array}{l}\text { 7. Made water channel surrounding roots and increasing } \\
\text { watering frequency }\end{array}$ & & $\sqrt{ }$ & & IALK \\
\hline & $\begin{array}{l}\text { 7. Pineapple and betel leaf root rotten, stem dying of } \\
\text { lemon tree, and lemon becomes discolored }\end{array}$ & Using organic and compost fertilizers, lime and oil cake & $\sqrt{ }$ & $\sqrt{ }$ & & CBALK \\
\hline & 8. Spread of invasive plant species & 8. Eradicate the plants through regular slash and clean-up & $\sqrt{ }$ & $\sqrt{ }$ & $\sqrt{ }$ & IALK \\
\hline & $\begin{array}{l}\text { 9. Increased human diseases (malaria, allergies, skin } \\
\text { and itching) }\end{array}$ & $\begin{array}{l}\text { 9. Uses of medicinal plants and mosquito nets as well as go to } \\
\text { physician for treatment }\end{array}$ & $\sqrt{ }$ & $\sqrt{ }$ & $\sqrt{ }$ & CBALK \\
\hline & 10. Decreasing growing season and crop productivity & 10. Changing planting time & $\sqrt{ }$ & $\sqrt{ }$ & & CBALK \\
\hline & & 11. Crop diversification and planting short rotational crops & $\sqrt{ }$ & $\sqrt{ }$ & & IPA \\
\hline & & 12. Homestead gardening & $\sqrt{ }$ & $\sqrt{ }$ & & IPA \\
\hline & 11. Pest and disease incidences in crops & Using extra pesticide, lime and oil cake & $\sqrt{ }$ & $\sqrt{ }$ & & CBALK \\
\hline & & 13. Planting hybrid crop varieties & $\sqrt{ }$ & $\sqrt{ }$ & & CBPA \\
\hline & 12. Loss of medicinal plants species & 14. Planting medicinal plant species in homestead & $\sqrt{ }$ & & & IALK \\
\hline \multirow{9}{*}{ High rainfall } & $\begin{array}{l}\text { 13. Increased water-borne diseases (diarrhea, dysentery } \\
\text { and skin diseases) }\end{array}$ & Uses of medicinal plants and go to physician for treatment & $\sqrt{ }$ & $\sqrt{ }$ & $\sqrt{ }$ & CBALK \\
\hline & 14. Landslide & 15. Construction of protection wall surrounding the locality & $\sqrt{ }$ & $\sqrt{ }$ & $\sqrt{ }$ & CBPA \\
\hline & & 16. Changing housing and staircases patterns & $\sqrt{ }$ & & $\sqrt{ }$ & СBРA \\
\hline & & 17. Planting more tree species surrounding the locality & $\sqrt{ }$ & $\sqrt{ }$ & & CBALK \\
\hline & 15. Soil erosion and leaching of soil nutrients & Rotational practices and mulching/covering soil with litter & $\sqrt{ }$ & $\sqrt{ }$ & & IALK \\
\hline & & 18. Terracing & & $y$ & $\sqrt{ }$ & CBPA \\
\hline & 16. Water logging and flash flood & $\begin{array}{l}\text { 19. Planting crops in heap and made water channel } \\
\text { surrounding roots }\end{array}$ & & $\sqrt{ }$ & $\sqrt{ }$ & IALK \\
\hline & 17. Loss of NTFPs in the most of the year & 20. Using improved cooking stove & $\sqrt{ }$ & $v$ & $\sqrt{ }$ & СВРА \\
\hline & & 21. Storing extra firewood and planting selected NTFPs plants & $\sqrt{ }$ & $\sqrt{ }$ & $\sqrt{ }$ & CBALK \\
\hline
\end{tabular}


Table 4. Cont.

\begin{tabular}{|c|c|c|c|c|c|c|}
\hline \multirow{2}{*}{ Climatic Event } & \multirow{2}{*}{ Observed Climate Change Impact } & \multirow{2}{*}{ Community-Based Adaptation Strategy } & \multicolumn{3}{|c|}{ Community $^{1}$} & \multirow{2}{*}{ Remark $^{2}$} \\
\hline & & & $\mathbf{K}$ & $\mathbf{T}$ & G & \\
\hline \multirow{5}{*}{$\begin{array}{l}\text { Heavy fog } \\
\text { and cold }\end{array}$} & 18. Decreasing growing season & Changing planting time & $\sqrt{ }$ & $\sqrt{ }$ & & CBALK \\
\hline & \multirow{4}{*}{$\begin{array}{l}\text { 19. Betel leaf becomes red cultured and leaf spot } \\
\text { 20. Lemon tree leaf becomes squeezed and } \\
\text { lemon discolored }\end{array}$} & Planting short rotational crops & $\sqrt{ }$ & $\sqrt{ }$ & & IALK \\
\hline & & 22. Early harvesting of crops & $\sqrt{ }$ & & $\sqrt{ }$ & CBALK \\
\hline & & Using organic and compost fertilizers & & $\sqrt{ }$ & & CBALK \\
\hline & & Early harvesting of crops & & $\sqrt{ }$ & & CBALK \\
\hline \multirow{10}{*}{$\begin{array}{l}\text { Natural } \\
\text { calamities }\end{array}$} & $\begin{array}{l}\text { 21. Betel leaf and lemon becomes discolored due } \\
\text { to hailstorm }\end{array}$ & Early harvesting of crop & $\sqrt{ }$ & $\sqrt{ }$ & $\sqrt{ }$ & CBALK \\
\hline & 22. Crop failure and economic loss & 23. Handicrafts business & $\sqrt{ }$ & $\sqrt{ }$ & & CBALK \\
\hline & & 24. Livestock rearing & $\sqrt{ }$ & $\sqrt{ }$ & & CBALK \\
\hline & & 25. Fish farming & $\sqrt{ }$ & & & CBPA \\
\hline & $\begin{array}{l}\text { 23. Behavioral change of wildlife (sightings of wild } \\
\text { animals in search of food and shelter) }\end{array}$ & $\begin{array}{l}\text { 26. Growing protection of crops through guard, build artificial } \\
\text { human-like doll and produce loud noises }\end{array}$ & $\sqrt{ }$ & & & CBALK \\
\hline & & $\begin{array}{l}\text { 27. Keep dry fish on betel leaf farm and garlic in houses to get } \\
\text { rid of monkey and snake respectively }\end{array}$ & $\sqrt{ }$ & & & CBALK \\
\hline & 24. Changing natural wind pattern & $\begin{array}{l}\text { Created shelterbelt by planting tree species surrounding the } \\
\text { locality }\end{array}$ & $\sqrt{ }$ & & & CBALK \\
\hline & & Changing housing patterns & $\sqrt{ }$ & & & CBPA \\
\hline & 25. Break down of seedlings and saplings & $\begin{array}{l}\text { 28. Used bamboo stick to protect seedlings and saplings from } \\
\text { wind breaks }\end{array}$ & & $\sqrt{ }$ & & IALK \\
\hline & 26. Breakdown of roads and culverts & 29. Construction and re-construction of roads and culverts & & $\sqrt{ }$ & & CBPA \\
\hline
\end{tabular}

${ }^{1}$ Community: K-Khasia, T-Tripura, G-Garo; ${ }^{2}$ IALK-Individual adaptation through local knowledge; IPA-Individual planned adaptation supported by government and NGOs; CBALK-Community-based adaptation through local knowledge; CBPA-Community-based planned adaptation supported by government and NGOs. 
Table 5. Management categories and classification of adaptation strategies.

\begin{tabular}{|c|c|c|c|c|}
\hline \multirow{2}{*}{ Adaptation Strategy } & \multirow{2}{*}{ Management Category ${ }^{1}$} & \multicolumn{3}{|c|}{ Classification $^{2}$} \\
\hline & & Ma & Me & Mi \\
\hline - Rainwater harvesting through digging pond and deeper well & WM & & & $\sqrt{ }$ \\
\hline - Setting water pump and storing water for household works & WM & & & $\sqrt{ }$ \\
\hline - Increased drainage facilities for the crops & WM & & & $\sqrt{ }$ \\
\hline - Terracing & SM & & & $\sqrt{ }$ \\
\hline - Mulching/increased soil cover through litter & SM & & $\sqrt{ }$ & \\
\hline - Construction of protection wall surrounding the locality & SM & & & $\sqrt{ }$ \\
\hline - Created shelterbelt by planting tree in the locality & SM & & & $\sqrt{ }$ \\
\hline - Changing patterns of housing and staircases & SM & & & $\sqrt{ }$ \\
\hline - Make water channel surrounding root, increasing watering frequency & $\mathrm{CM}$ & & $\sqrt{ }$ & \\
\hline - Using compost and organic fertilizers, lime and oil cake, planting hybrid variety of species & $\mathrm{CM}$ & & $\sqrt{ }$ & \\
\hline - Planting crops in heap & $\mathrm{CM}$ & & & $\sqrt{ }$ \\
\hline - Eradicate invasive species through regular slash and clean-up & $\mathrm{CM}$ & & $\sqrt{ }$ & \\
\hline - Rotational practices & $\mathrm{CM}$ & & $\sqrt{ }$ & \\
\hline - Changing planting time & $\mathrm{CM}$ & & $\sqrt{ }$ & \\
\hline - Early harvesting of crops & $\mathrm{CM}$ & & $\sqrt{ }$ & \\
\hline - Planting seedlings with covering and gap filling & $\mathrm{CM}$ & & & $\sqrt{ }$ \\
\hline - Crop diversification/multiple production & $\mathrm{CM}$ & & $\sqrt{ }$ & \\
\hline - Used bamboo stick to protect seedlings and saplings from wind breaks & $\mathrm{CM}$ & $\sqrt{ }$ & & \\
\hline - Using improved cooking stove & EM & & & $\sqrt{ }$ \\
\hline - Storing extra firewood and planting selected NTFPs plants in homestead & EM & & & $\sqrt{ }$ \\
\hline - Increased tree species in homestead and farms & $\mathrm{IM}$ & & $\sqrt{ }$ & \\
\hline - Planting and uses of medicinal plants for curing diseases & $\mathrm{IM}$ & & & $\sqrt{ }$ \\
\hline - Handicrafts, livestock rearing and fish farming & IM & & & $\sqrt{ }$ \\
\hline - Construction and re-construction of roads and culverts & PM & $\sqrt{ }$ & & \\
\hline - Increasing protection of crops from wildlife & PM & & & $\sqrt{ }$ \\
\hline - Building resting places alongside road in the Tea Estate & PM & $\sqrt{ }$ & & \\
\hline - Keep dry fish on betel leaf farm and garlic in houses to get rid of monkey and snake respectively & PM & & $\sqrt{ }$ & \\
\hline
\end{tabular}

${ }_{1}^{1}$ Management category: WM-Water Management, SM-Soil Management, CM-Crop Management, EM-Energy Management, IM-Income Management, PM-Production Management; ${ }^{2}$ Classification: Ma-Materials adaptation, Me-Methodical adaptation, Mi-Mixed adaptation. 


\subsection{Water Management Strategies}

\subsubsection{Setting Water pump for Daily Work and Irrigation Water}

The scarcity of drinking and irrigation water was found to be the most frequent impact of climate change in the LNP. To cope with this adverse effect, the indigenous communities set up diesel or kerosene-run water pumps near their houses (Figure 4a). They usually penetrate a 50-60-foot-long iron pipe into the ground to lift underground water. Later, they supply the water via plastic pipes to the whole locality for household use, and for watering and irrigating the agroforesty farms. Sometimes, the farmers also use buckets or different plastic containers to carry water from the pump site.

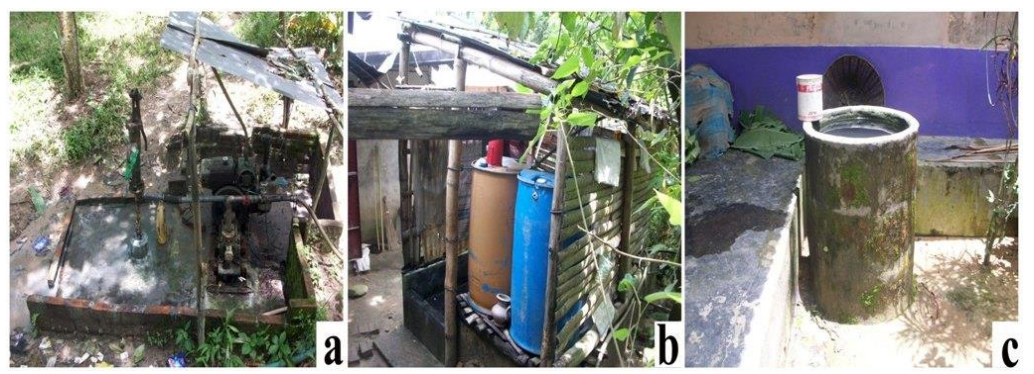

Figure 4. (a) Setting water pump; storing water in (b) plastic drum and (c) cemented rings.

\subsubsection{Storing Water in Reservoir}

Communities used big plastic drums (Figure $4 \mathrm{~b}$ ) and cemented rings (Figure 4c) as reservoirs for storing water contrary to their past practices. The women for their household works and bathing only use these reservoirs, located inside or just at the door of the house. In the past, they used water from natural streams and wells for their domestic works; however, nowadays, they depend on water collected from water pumps, ponds or deep wells.

\subsubsection{Rainwater Harvesting through Digging Pond and Well}

During the summer or even in the monsoon, the indigenous communities follow different rainwater harvesting techniques, such as storing water mainly for irrigation purposes, as well as domestic uses where the most common technique is to store water in square and circular-structured mini ponds and wells. Some farmers excavate larger ponds as needed-located almost at the centre-near or corner of the farms and houses, so that the community people can easily use it (Figure 5). Some farmers use plastic buckets or containers to carry water from the ponds or wells to irrigate their agroforestry farms, which are far from the water sources. The Khasia community have also dug small ponds at the top of the hills to store water for irrigating their betel leaf farms during the summer and drought.

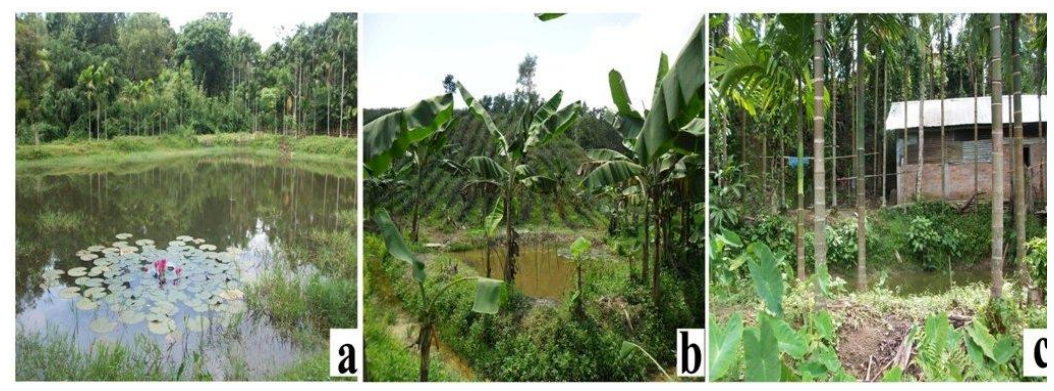

Figure 5. Rainwater harvesting through digging pond by the indigenous communities. 


\subsubsection{Increasing Drainage Facilities for the Crops}

The Tripura and Garo communities have dug small drains beside their farms to remove excess water during rainy season, thereby avoiding water-logging conditions after rain and flash floods. Drains are also used for irrigation purposes in summer as well as during periods of less rainfall or drought. Depending on the conditions, those drains are usually renovated seasonally or annually before rain season starts.

\subsection{Crop Management Strategies}

\subsubsection{Crop Diversification/Multiple Production}

Indigenous communities have cultivated multiple crops (horticultural crops, fruit species, maize and paddy) following a systematic spatial arrangement that maintains a harmonic production of all the species at a time. In addition, they cultivated seasonal short rotational crops (maize, paddy, papaya, zinger, turmeric, chillies and vegetables), banana cultivation in betel leaf, lemon and pineapple agroforestry farms, and jackfruit cultivation in lemon and pineapple agroforestry farms throughout the year. Multiple crops serve as insurance to the farmers as when one crop gets damaged due to adverse climatic events, another crop provides the farmers with income, thus helping them to minimize the total loss. This kind of practice gives a good turnover in terms of yield, reduces the soil erosion, loss of soil nutrients and fertility.

\subsubsection{Change in Planting and Harvesting Time}

Monsoon usually appears in Bangladesh in June, but now it appears in late April or early May. Winter used to appear in November, but now it appears in late December where irregular rainfall occurs more than two times in a year. The overall growing season has also decreased to about 2-4 months in a year due to abnormality in the weather. As a result, sowing, planting and harvesting time continues to change, which hampers the productivity of crops as their cultivation practices rely on seasonal rainwater.

\subsubsection{Using Pesticide, Fertilizers and Hybrid Variety}

In the last few years, agroforestry crops have been severely attacked by new types of pests, diseases and insects such as leaf and root rot, leaf spot, stem dying, discoloration of fruit and leaf as well as by the quick spread of invasive species. To ensure protection against pest and diseases, farmers need to spray an extra amount of pesticide and insecticide despite its being harmful to the environment. Farmers were found using organic (cow dung, oil cake and compost) and inorganic fertilizers (NPK), and cultivating hybrid varieties to ensure a better yield.

\subsubsection{Protection of Seedlings and Saplings}

To protect the newly planted seedlings and saplings from extreme heat and drought condition, Tripura and Garo communities were planting seedlings with a circular or square cover made by plastic and bamboo. Communities also filled the seedling gaps with a new and physically strong seedling soon after a seedling dies. Moreover, the Tripura community also uses bamboo sticks to protect the lemon trees from windbreaks. More than one bamboo stick was used in a circular way to keep the seedlings and saplings upright.

\subsubsection{Planting Crops in Heap and Make Drain Surrounding the Root}

To minimize the effect of heavy rainfall and water logging condition during the monsoon, farmers tend to grow their crops in heaps. With this practice, the crop always remains in a high platform where rainwater cannot accumulate around the root. Communities also prepare channels surrounding the lemon root, which helps to hold water for a few days during the summer or the drought period. 


\subsection{Soil Management Strategies}

\subsubsection{Mulching/Covering Soil with Litter and Leaves}

The Khasia and Tripura communities use mulching/covering soil of crops with the help of fallen litter, leaves and slash wastes. Such a strategy reduces soil erosion and leaching of soil nutrients, increases soil moisture content and fertility (organic fertilizer), and keeps soil temperature relatively low. In the past, they used to utilize these fallen materials as fuel.

\subsubsection{Terracing}

Tripura farmers were found making terraces within the slopes of the denuded hills to grow lemon-based agroforestry with different crops such as various spices, banana, and pineapple. Although it has a negative impact, it is widely used as a soil conservation method because it prevents the soil nutrients of the upper soil from being washed away.

\subsubsection{Construction of Protection Wall}

The Khasia and Garo communities live at the top of the hills, whereas the Tripura community lives in a relatively flat area. All groups face landslide and soil erosion problems. To cope with this, they construct protection walls with bricks, cement and iron rod, and plant more trees around their houses and locality to provide effective protection for houses and farms (Figure 6a,b). Concerning this, they have received financial and technical support from local NGOs working in the area.
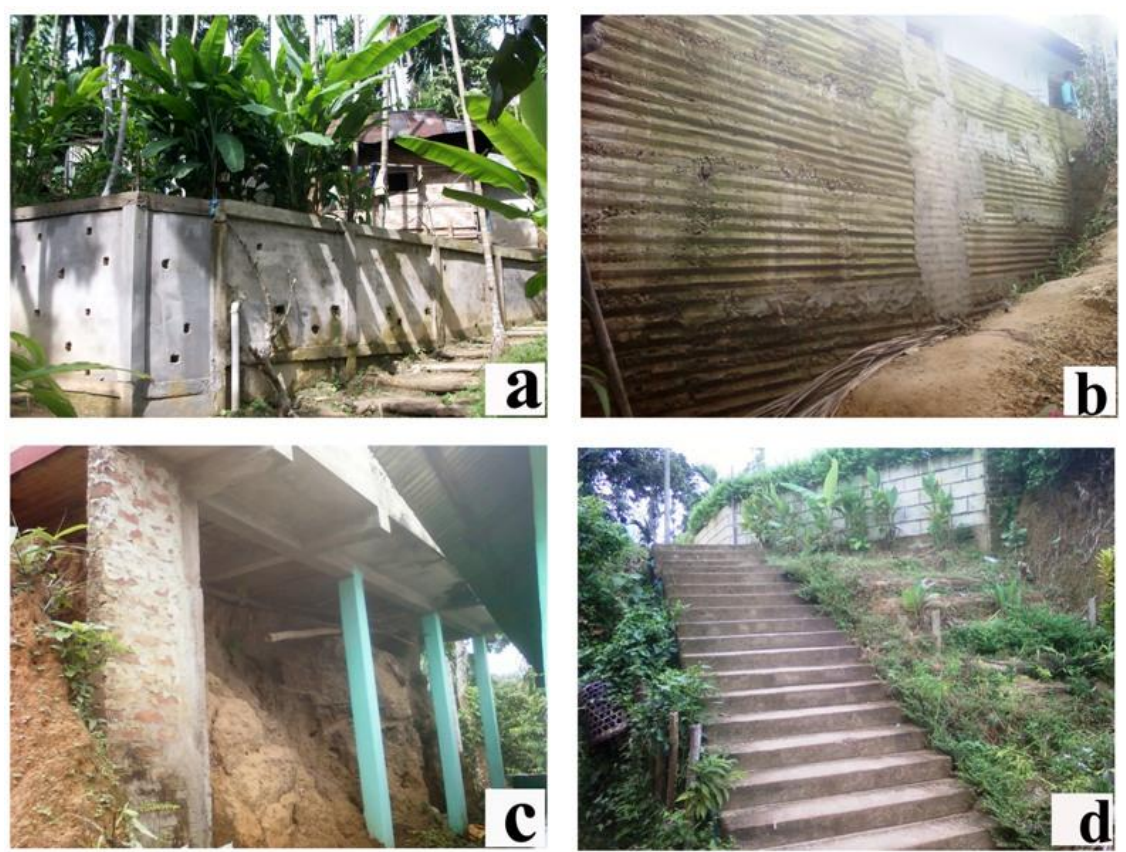

Figure 6. Construction of protection wall surrounding the (a) houses and (b) locality; changing design and patterns of $(\mathbf{c})$ houses and $(\mathbf{d})$ staircases.

\subsubsection{Changing Patterns of Houses and Staircases}

The Khasia community changed the patterns of their houses by converting them into tin-shed and semi-pucca buildings (partially brick-built) supported by long pillars (Figure 6c). Both Khasia and Garo communities changed the patterns of their homestead staircases (the only way of entering the villages at the top of the hills) with cemented bricks, bamboo and tree poles. A shift in their house-making style has been reported, whereas in the past they were made of mud only. They also brought about changes in the design of the staircases by making them curved instead of straight (Figure 6d). 


\subsection{Production Management Strategies}

Roads and culverts of this area have been damaged by landslide, soil erosion and flash floods, which have hampered the communication system and transportation of agroforestry crops to the market. Government and NGOs construct and re-construct roads and culverts with community participation. One study found that, without the improved communication system, buyers do not show interest in procuring agroforestry produces that are likely to cause pecuniary losses. Additionally, to protect the tea garden laborers (Garo) and passers-by from extreme heat, the Jerin Tea Estate Company built several permanent shades alongside the road. These shades are being used temporarily for gathering tea leaves after plucking to protect them from being squeezed and discolored.

\subsection{Energy Management Strategies}

Indigenous communities that have been studied are heavily dependent on forests for their daily household fuel needs. To minimize the use of forest fuels, NSP developed a program for the introduction of improved cooking stoves (ICS) in 2004 with the technical assistance from the German Society for International Cooperation (GIZ). The NSP along with Grameen Shakti, a national NGO, have collaborated to launch a program to promote the ICS among the indigenous communities in the LNP. The ICSs were distributed to the communities intending to make them less dependent on forest woods, which resulting in their saving $50 \%-70 \%$ of their fuel, as they claim. This environment-friendly stove emits less carbon into the air and thereby helps mitigate climate change at a micro-site level. Moreover, communities have a tendency to storing more firewood to address the situation of irregular rainfall and other natural calamities that can strike at any time of the year. Generally, the Khasia and Tripura communities collect firewood from agroforestry farms, and Garo from Tea gardens and forests.

\subsection{Income Management Strategies}

Negative impacts of climate change reduce the scope of traditional livelihoods, leading the community people to look for different IGAs. Since 2004, microcredit-led NGOs, banks and donor supported projects promoted the IGAs for the forest-dependent indigenous communities. The IGAs vary as per communities' needs, such as poultry and livestock rearing, fish farming (only Khasia), nursery production, ICS manufacture and selling, eco-tourism, eco-lodge and eco-guiding, tribal cloths, bamboo and rattan-based handicrafts manufacture, firewood and medicinal plants cultivation, sewing machine to the woman, setting-up grocery and tourist shops. Moreover, the Khasia and Tripura communities' increasing number of tree species in homestead and agroforestry farms. Short rotational (5-10 years) plants, medicinal and woodlots were preferred under this adaptation. Trees also saved the community houses and crops from wind, storm, raindrop, lightning and hailstorm.

\section{Discussion}

Indigenous communities have long been recognized as vulnerable to the impacts of climate change due to the close connection between forest, their livelihoods, culture, spirituality and socio-ecological systems and their environment. In contrast to that, their local knowledge, resource management practices, and adaptation strategies are all considered important for both mitigating and adapting to climate change. The present study sought the level of awareness about climate change and its impact among the respondents, where less than half of the respondents (39.8\%) had knowledge about the issue. The study also reveals that, although about $60.2 \%$ respondents do not understand the scientific causes and consequences of climate change, their long-term observations on the changing weather patterns (temperature, rainfall, etc.) is very impressive as they interact directly with the nature. Similar observations have also been found by Mahmood et al. [7], Anik and Khan [9], Chaudhary and Bawa [16], Byg and Salick [45], Mertz et al. [46] and Apata [47], all of which indicate that climate is changing, while some other studies, such as Chaudhary and Bawa [16], Chaudhary et al. [17], Hageback et al. [48], Cabrera et al. [49], Thomas et al. [50] and Shrestha et al. [51] have validated 
community perception with scientific evidence. Interestingly, indigenous people from tropical forest areas have reported that natural signals that were used to trigger activities in the past are now less reliable as the weather becomes hotter and the rainy season comes earlier or later than usual, which can lead to a disorientation of people in their daily lives [52].

Another survey revealed that in recent years indigenous communities received some climate change-related information from the CREL project and through media (mainly radio, television, etc.) In line with this research, other studies, e.g., Byg and Salick [45] and Boykoff [53], have stated that media could play a decisive role in shaping people's perceptions about climate change. However, media has less interest in covering this issue on a daily basis. Some $78 \%$ respondents reported environmental change in the LNP due to illegal logging, over-exploitation of resources, plantation of exotic tree species, farmland expansion by both Bengali and indigenous communities inside the forest, wildlife hunting, destruction of natural regeneration, and wildlife habitat for farming and plantation.

On the other hand, about the issue of climate change awareness in the future, approximately $69.9 \%$ respondents reported that the awareness raising program and capacity-building training on adaptation are needed immediately because this is a critical issue and barrier towards achieving their sustainable livelihoods and environmental management ( $82.8 \%$ ). Among the respondents, those below 40 years old $(63.4 \%)$ have better knowledge about the climate change issue than those above 40 years $(36.6 \%)$. At the same time, the Khasia $(61.5 \%)$ community had more knowledge about climate change than the Tripura $(38.5 \%)$ and Garo $(8.3 \%)$ communities. The reasons behind that include age, gender, access to information, economic status, and the literacy rate. The Khasia community is literate $66.7 \%$ literate and can only sign $21.2 \%$, whereas Tripura is $57.5 \%$ literate and can only sign $25 \%$, and Garo is $25 \%$ literate and can only sign $30 \%$. Patt and Schröter [54] stated that climate change perception is highly contingent on the social, cultural, and economic conditions of the communities that lead to their behavioral change. In addition, some studies such as those by Byg and Salick [45], van Aalst et al. [55], Alessa et al. [56], Laidler [57] and Danielsen et al. [58] have pointed out that documenting local knowledge and community perceptions of climate change is important in decision-making whether they can act or not, since local perceptions reflect local concerns and focus on the actual impacts on people's lives.

The present study reveals that, due to rising temperature and change in rainfall patterns, agroforestry crops are damaged, and growth and yield decrease. Persistent cold wave accompanied by dense fog badly affects the crops during winter. Severe cold and excessive fog cause dropping of betel leaves and the leaves become red, lemon leaves become squeezed, and spot/discoloration of betel leaves and lemon and root rot of pineapple occur. Moreover, stems of betel leaves and lemon trees die, and disease spreads commonly throughout the farm in the LNP area, which has been supported by the findings of Vedwan and Rhoades [23], Saha and Azam [30], Rosenzweig et al. [59] and Pautasso et al. [60]. As a response to climate change, crop management strategies such as introduction of new crop varieties, crop diversification, and change in planting and harvesting time are common, which shows better adaptability by enhancing crop diversity, increasing overall crop yield, and diversify local diets $[16,17,60-63]$. In Philippines, forest-dependent smallholder farmers have been suffering from delayed fruiting of fruit trees, higher incidence of pests and diseases, etc. in agriculture and agroforestry farms due to changes in rainfall and temperature patterns. To coping with these, they cultivated multiple cropping or intercropping, increased use of fertilizers and pesticides, adjusting their planting calendars, and diversifying livelihoods [64].

Unlike the present research, the Himalayan people have been finding mosquitoes, have experienced malaria and skin diseases, and have seen wild boar, deer and new species of wasps and bees in higher altitudes that were non-existent 5-10 years ago [17,64-66]. Forest-dependent indigenous people in Chittagong Hill Tracts of Bangladesh are highly vulnerable to climate change-induced diseases such as increasing mosquitoes and mosquito-borne diseases [18,67]. Similarly, people in other climate-sensitive areas of Bangladesh are suffering from water-borne diseases (e.g., diarrhoea, 
dysentery and skin diseases), vector-borne diseases (e.g., malaria, vomiting, dengue fever, etc.) as well as mental disorders [68,69].

For conservation adaptive management and idea of climate resilience related to local knowledge are important among the indigenous communities and other local resource-dependent groups [70]. International Centre for Integrated Mountain Development (ICIMOD) [71] explained that the prospect of short- and medium-term climate resilient development in mountain areas of Nepal is limited due to persistent climate uncertainty, and "no-regret" strategies are needed regardless of the direction or magnitude of change. Some other studies indicate that communities do perceive that the climate is changing and need to adapt to reduce the negative impacts [46,72], and adaptive measures are largely contingent upon the socio-economic and environmental factors [73,74]. In this lieu, Platform for Agrobiodiversity Research (PAR) [75] developed a model of adaptation dynamics at different levels contributing to the resilience of the whole system through (i) the links between natural and cultivated ecosystem/landscapes (to mitigate and buffer the effects of climate change through ecosystem protection and restoration, landscape rehabilitation and the sustainable use of natural resources); (ii) the supportive role of agriculture/crop production in the protection and restoration of ecosystems (local food systems is enhanced through the diversification and sustainable management of water and soil); and (iii) the maintenance of species and genetic diversity (strengthen the resilience of agricultural systems and maintain production in stress-prone environments). The model also puts a special focus on the social and community dimensions of adaptation. Based on the present study, the model also reveals that affected community should be involved in the decision-making process when developing community-based climate change awareness and capacity building programs on conservation linked to alternative livelihood and forest protection.

However, Spittlehouse and Stewart [15] presented an extensive list of adaptive strategies proposed for forest protection and resources management. In semi-arid and arid regions, several technologies based on local knowledge have been developed to conserve and harvest scarce water resources in traditional silvopastoral and agroforestry systems [76]. In Africa, for example, indigenous people cultivate different varieties of crops that are tolerant to climate change, using organic or inorganic fertilizers and shortening of growing season [46,72,77]. Notably, many people say prayers and observe rituals for protecting their crops in Africa [54]. In Northeastern India, the soil and vegetation management practices have been developed over generations by local communities to enhance soil fertility and minimize soil erosion [78]. Boon and Ahenkan [20] reported that Sui River Forest Reserve communities adopted different strategies, such as tree planting and NTFPS farming, high yielding and drought resistance varieties of species, practice of the "Taungya System," a form of agrisilviculture, or farm forestry, whereby cultivate agricultural crops during the early stages of forest plantation establishment, and rainwater harvesting, that minimize the impacts of climate change. Adger et al. [79] conducted a study in the Hindu Kush-Himalayan region and recommend that they need to have a much better understanding about the mountain communities' traditional knowledge of strategies to respond to climate variability in order to identify key determinants for future adaptation.

\section{Conclusions}

Climate change has multiple effects on indigenous communities' livelihoods, mostly on their farming systems, forest ecosystem and biodiversity. The local knowledge can be a good point of departure for the scientists testing specific hypotheses, and to policy makers for designing apposite adaptation and mitigation strategies to address the challenges of climate change. Studied indigenous communities have undertaken the number of adaptation strategies drawing on their local knowledge combined with using modern tools and techniques. The purpose is to make the adaptation more robust, reliable, replicable, relevant, remedial, and resilient and resource-conserving in nature against the negative impacts of climate change. However, those strategies are inadequate for their sustainable livelihood for which urgent technical support and awareness-raising programs are to be launched where the programs must be more sector-specific, considering gender, ethnicity and economic 
conditions of the communities. Unabated research and long-term investment in forest sector are indispensable for augmenting the well-being of the affected people. Government and NGOs need to support the smallholder indigenous farmers in terms of resource accumulation; research on how to enhance the adaptive capacity and mitigation competence of communities for coping with the additional stress created by climate change and increasing climate variability needs to be carried out. Finally, the future REDD+ (reducing emissions from deforestation and forest degradation in developing countries, and the role of conservation, sustainable management of forests and enhancement of forest carbon stocks) mechanism should carefully weigh up the concerns and interests of indigenous communities, as well as their current and potential contributions to the conservation and sustainable management of Bangladesh forests in general and LNP in particular.

Acknowledgments: This study has been supported by the Bangladesh Institute of Social Research (BISR) Trust under its "Adjunct Researcher Fellowship" program for the first author. We express our deep gratitude to the inhabitants of the four study villages for their heartiest cooperation, hospitality and information-sharing. Heartiest thanks also goes to field guide and Bishwajit Roy for their friendly support during field surveys. Special thanks are due to Mohammed Abu Sayed Arfin Khan for useful suggestions on an earlier version of this article.

Author Contributions: Md. Habibur Rahman had designed the study, conducted field research, analyzed the data and prepared the manuscript. Khurshed Alam provided support for the design of the study, and contributed significantly to the writing and finalization of the manuscript.

Conflicts of Interest: The authors declare no conflict of interest.

\section{Appendix}

\section{Key Components of the Survey Questionnaire and Checklists}

(1) What types of climate-related natural hazards are common in Lawachara National Park?

\begin{tabular}{|c|c|c|c|}
\hline Serial Number & Climatic Hazard & Response & Frequency/Year Intensity \\
\hline 01 & Increasing temperature & & \\
\hline 02 & High rainfall & & \\
\hline 03 & Low rainfall & & \\
\hline 04 & Irregular rainfall & & \\
\hline 05 & Landslide, soil erosion and flash flood & & \\
\hline 06 & Drying up of stream and well & & \\
\hline 07 & Natural calamities & & \\
\hline 08 & Heavy fog and cold & & \\
\hline 09 & Others (specify) & & \\
\hline
\end{tabular}

Code: Response: 1 = Yes, 2 = No, 3 = No comments; Frequency/year: 1,2,3, . ; Intensity: 1 = Very low or no risk, 2 = Low risk, 3 = Medium risk, $4=$ High risk, 5 = Very high risk.

(2) Observed climate change impacts on production of agroforestry crops (put $\sqrt{ }$ ).

\begin{tabular}{|c|c|c|c|c|}
\hline \multirow{2}{*}{$\begin{array}{c}\text { Serial } \\
\text { Number }\end{array}$} & \multirow{2}{*}{$\begin{array}{c}\text { Farming } \\
\text { Hazard }\end{array}$} & $\begin{array}{c}\text { Betel Leaf } \\
\text { Agroforestry }\end{array}$ & $\begin{array}{c}\text { Pineapple } \\
\text { Agroforestry }\end{array}$ & Lemon Agroforestry \\
\hline & & Khasia Tripura Garo & Khasia Tripura Garo & Khasia Tripura Garo \\
\hline 02 & High rainfall & & & \\
\hline 03 & Low rainfall & & & \\
\hline 04 & Irregular rainfall & & & \\
\hline 06 & Drying up of stream and well & & & \\
\hline 07 & Natural calamities & & & \\
\hline 08 & Heavy fog and cold & & & \\
\hline 09 & Others (specify) & & & \\
\hline
\end{tabular}


(3) Agroforestry wise climate change impacts and adaptation by the indigenous communities.

\begin{tabular}{|c|c|c|c|c|c|}
\hline Agroforestry & Climatic Hazard & $\begin{array}{l}\text { Observed } \\
\text { Impacts }\end{array}$ & $\begin{array}{c}\text { Adaptation } \\
\text { Measures }\end{array}$ & Initiated by & $\begin{array}{l}\text { Community } \\
\text { Involve }\end{array}$ \\
\hline \multicolumn{6}{|c|}{ Increasing temperature } \\
\hline \multicolumn{6}{|c|}{ High rainfall } \\
\hline \multicolumn{6}{|c|}{ Low rainfall } \\
\hline \multicolumn{6}{|c|}{ Irregular rainfall } \\
\hline \multicolumn{6}{|c|}{ Landslide, soil erosion and flash flood } \\
\hline & Drying up of stream and well & & & & \\
\hline \multicolumn{6}{|c|}{ Natural calamities } \\
\hline \multicolumn{6}{|c|}{ Heavy fog and cold } \\
\hline \multicolumn{6}{|c|}{ Others (specify) } \\
\hline
\end{tabular}

Code: Agroforestry: 1 = Betel leaf, 2 = Pineapple, 3 = Lemon; Initiated by: 1 = Applying own local knowledge, 2 = Individually planned supported by government/NGO, 3 = Applying local knowledge by the whole community, 4 = Community-based planned adaptation supported by government/NGO; Community involve: $1=$ Khasia, 2 = Tripura, $3=$ Garo .

(4) Climate change impacts on indigenous community livelihoods.

\begin{tabular}{|c|c|c|c|}
\hline Area of Impact & Climatic Hazard & Observed Impacts & Community Involve \\
\hline & Increasing temperature & & \\
\hline & High rainfall & & \\
\hline & Low rainfall & & \\
\hline & Irregular rainfall & & \\
\hline & Landslide, soil erosion and flash flood & & \\
\hline & Drying up of stream and well & & \\
\hline & Natural calamities & & \\
\hline & Heavy fog and cold & & \\
\hline & Others (specify) & & \\
\hline
\end{tabular}

Code: Area of impact: 1 = Agriculture and food security, $2=$ Scarcity of water, $3=$ Human health, $4=$ Income, 5 = Spiritual belief; Community involve: $1=$ Khasia, $2=$ Tripura, $3=$ Garo .

(5) Climate change impacts on forest ecosystem.

\begin{tabular}{|c|c|c|c|}
\hline Area of Impact & Climatic Hazard & Observed Impacts & Community Involve \\
\hline & Increasing temperature & & \\
\hline & High rainfall & & \\
\hline & Low rainfall & & \\
\hline & Irregular rainfall & & \\
\hline & Landslide, soil erosion and flash flood & & \\
\hline & Drying up of stream and well & & \\
\hline & Natural calamities & & \\
\hline & Heavy fog and cold & & \\
\hline & Others (specify) & & \\
\hline
\end{tabular}

Code: Area of impact: 1 = Forest resources, $2=$ Wildlife, $3=$ Soil characteristics, $4=$ Water availability; Community involve: $1=$ Khasia, $2=$ Tripura, $3=$ Garo .

(6) Community attitudes towards forest conservation: value the forest for your future needs, importance of forest protection, community role to protect forest, scope of community participation in forest management, etc.

(7) Awareness and benefits of technical aspect of adaptation measures supported by external agencies.

(8) Willingness of community to continuation of the adaptation measures after withdrawal of the support. 
(9) Now, what is your knowledge and understanding about the changing climate and weather patterns in Lawachara forest?

\begin{tabular}{ccc}
\hline Serial Number & Knowledge and Understanding & Code \\
\hline 01 & I have very good knowledge & 5 \\
02 & I have good knowledge & 4 \\
03 & I have no knowledge & 3 \\
04 & I am not clear & 2 \\
05 & No comments & 1 \\
\hline
\end{tabular}

\section{References}

1. IPCC. Climate Change 2007: Impacts, Adaptation and Vulnerability-Contribution of Working Group II to the Fourth Assessment Report of the Intergovernmental Panel on Climate Change; Cambridge University Press: Cambridge, UK, 2007.

2. Food and Agriculture Organization of the United Nations (FAO). Adaptation to Climate Change in Agriculture, Forestry and Fisheries: Perspective, Framework and Priorities; FAO Inter-Departmental Working Group on Climate Change: Rome, Italy, 2007.

3. Ayers, M.J.; Huq, S. The value of linking mitigation and adaptation: A case study of Bangladesh. Environ. Manag. 2008, 43, 753-764. [CrossRef] [PubMed]

4. Ministry of Environment and Forests (MoEF). Bangladesh Climate Change Strategy and Action Plan 2008; Ministry of Environment and Forests, Government of Bangladesh: Dhaka, Bangladesh, 2008.

5. Ahmed, A.U. Adaptability of Bangladesh's crop agriculture to climate change: Possibilities and limitations. Asia Pac. J. Environ. Develop. 2001, 7, 71-93.

6. Islam, T.; Atkins, P.J. Indigenous floating cultivation: A sustainable agricultural practice in the wetlands of Bangladesh. Develop. Prac. 2007, 17, 130-136. [CrossRef]

7. Mahmood, S.M.S.; Najneen, F.; Hoque, K.S.; Rahman, S.; Shamim, M.M. Climate change: A study on impact and people's perception (A case study on MonglaUpazila, Bagerhat District, Bangladesh). Bangladesh Res. Pub. J. 2010, 4, 153-164.

8. Alam, K. Adaptation of coastal dwellers: The case of Bangladesh. Man. Develop. 2011, 33, 91-112.

9. Anik, S.I.; Khan, M.A.S.A. Climate change adaptation through local knowledge in the north eastern region of Bangladesh. Mitig. Adapt. Strat. Glob. Change 2012, 17, 879-896. [CrossRef]

10. Ravindranath, N.H.; Joshi, N.V.; Sukumar, R.; Saxena, A. Impact of climate change on forest in India. Curr. Sci. 2006, 90, 354-361.

11. Locatelli, B.; Kanninen, M.; Brockhaus, M.; Colfer, C.J.P.; Murdiyarso, D; Santoso, H. Facing an Uncertain Future: How Forests and People Can Adapt to Climate Change; Center for International Forestry Research (CIFOR): Bogor, Indonesia, 2008.

12. Seppälä, R.; Buck, A.; Katila, P. Adaptation of Forests and People to Climate Change-A Global Assessment Report; International Union of Forest Research Organizations (IUFRO): Helsinki, Finland, 2009.

13. World Bank. Forests Sourcebook: Practical Guidance for Sustaining Forests in Development Cooperation; World Bank: Washington, DC, USA, 2008.

14. Sobrevila, C. The Role of Indigenous Peoples in Biodiversity Conservation: The Natural But Often Forgotten Partners; World Bank: Washington, DC, USA, 2008.

15. Spittlehouse, D.L.; Stewart, R.B. Adapting to climate change in forest management. BC. J. Ecosys. Manag. 2003, 4, 7-17.

16. Chaudhary, P.; Bawa, K.S. Local perceptions of climate change validated by scientific evidence in the Himalayas. Biol. Lett. 2011, 7, 767-770. [CrossRef] [PubMed]

17. Chaudhary, P.; Rai, S.; Wangdi, S.; Mao, A.; Rehman, N.; Chettri, S.; Bawa, K.S. Consistency of local perceptions of climate change in the Kangchenjunga Himalaya landscape. Curr. Sci. 2011, 101, 504-513. 
18. Fardous, S. Perception of climate change in Kaptai National Park. In Rural Livelihoods and Protected Landscape: Co-Management in the Wetlands and Forests of Bangladesh; Fox, J., Mustafa, M.G., Quazi, S.A., Miles, W.B., Cunningham, E.J., Chassels, M., Eds.; Nishorgo Network: Dhaka, Bangladesh, 2011; pp. 186-204.

19. Kebebew, Z.; Urgessa, K. Agroforestry perspective in land use pattern and farmers coping strategy: Experience from Southwestern Ethiopia. World J. Agricul. Sci. 2011, 7, 73-77.

20. Boon, E.; Ahenkan, A. Assessing climate change impacts on ecosystem services and livelihoods in Ghana: Case study of communities around Sui Forest Reserve. J. Ecosys. Ecogra. 2012, S3, 1-8. [CrossRef]

21. Parrotta, J.A.; Agnoletti, M. Traditional Forest-Related Knowledge and Climate Change: Sustaining Communities, Ecosystems and Biocultural Diversity; Springer: Dordrecht, The Netherlands, 2012.

22. Couzin, J. Opening doors to indigenous knowledge. Science 2007, 315, 1518-1519. [CrossRef] [PubMed]

23. Vedwan, N.; Rhoades, R.E. Climate change in the Western Himalayas of India: A study of local perception and response. Clim. Res. 2001, 19, 109-117. [CrossRef]

24. McLean, K.G. Advance Guard: Climate Change Impacts, Adaptation, Mitigation and Indigenous Peoples-A Compendium of Case Studies; United Nations University-Traditional Knowledge Initiative: Darwin, Australia, 2010.

25. Miah, M.D.; Akther, S.; Shin, M.Y.; Koike, M. Scaling up REDD+ strategies in Bangladesh: A forest dependence study in the Chittagong Hill Tracts. For. Sci. Tech. 2014, 10, 148-156. [CrossRef]

26. Miah, M.D.; Ahmed, F.U. Conservation of a tropical wet semi-evergreen forest ecosystem by an indigenous community in the Bandarban hill district of Bangladesh: The role of intervention. Small Scale For. 2014, 13, 319-331. [CrossRef]

27. Rahman, M.H.R.; Fardusi, M.J. Indigenous plant utilization and farming system of Garo tribe in north-east Bangladesh: A means of sustainable biodiversity conservation. J. For. Sci. 2012, 28, 84-96. [CrossRef]

28. Miah, M.D.; Chowdhury, M.S.H. Traditional forest utilization practice by the Mro. tribe in the Bandarban region, Bangladesh. Swiss J. For. 2004, 155, 65-70.

29. Khan, N.A.; Alam, M.K.; Khisa, S.K. The Case for Farming Practices and Sustainable Development in the Chittagong Hill Tracts. In Farming Practices and Sustainable Development in the Chittagong Hill Tracts; Chittagong Hill Tracts Development Board: Chittagong, Bangladesh, 2002; pp. 1-8.

30. Saha, N.; Azam, M.A. The indigenous hill-farming system of Khasia. tribes in Moulvibazar district of Bangladesh: Status and impacts. Small Scale For. 2004, 3, 273-281.

31. Nath, T.K.; Inoue, M. Forest villagers in northeastern hill forests of Bangladesh: Examining their livelihoods, livelihood strategies and forest conservation linkages. Small Scale For. 2014, 13, 201-217. [CrossRef]

32. Nath, T.K.; Inoue, M. Sustainability attributes of a small-scale betel leaf agroforestry system: A case study in north-eastern hill forests of Bangladesh. Small Scale For. 2009, 8, 289-304. [CrossRef]

33. Burling, R. The Strong Women of Modhupur; University Press Limited: Dhaka, Bangladesh, 1997.

34. Center for Natural Resources Studies (CNRS). Lawasera, Tropical Forest of Bangladesh, Rapid Rural Appraisal (RRA) Findings; Center for Natural Resources Studies: Dhaka, Bangladesh, 2000.

35. Nath, T.K.; Inoue, M.; Islam, M.J.; Kabir, M.A. The Khasia tribe of northeastern Bangladesh: Their socioeconomic status, hill farming practices and impacts on forest conservation. For. Trees Liveli. 2003, 13, 297-311. [CrossRef]

36. Pretty, J.; Bharucha, Z.P. Sustainable intensification in agricultural systems. Ann. Bot. 2014, 10. [CrossRef] [PubMed]

37. Nath, T.K.; Jashimuddin, M.; Hasan, M.K.; Shahjahan, M.; Pretty, J. The sustainable intensification of agroforestry in shifting cultivation areas of Bangladesh. Agroforest Syst. 2015, 10, 1-12. [CrossRef]

38. Verchot, L.V.; Noordwijk, M.V.; Kandji, S.; Tomich, T.; Ong, C.; Albrecht, A.; Mackensen, J.; Bantilan, C.; Anupama, K.V.; Palm, C. Climate change: Linking adaptation and mitigation through agroforestry. Mitig. Adapt. Strat. Glob. Change 2007, 12, 901-918. [CrossRef]

39. Nair, P.K.R.; Kumar, B.M.; Nair, V.D. Agroforestry as a strategy for carbon sequestration. J. Plant. Nutr. Soil Sci. 2009, 172, 10-23. [CrossRef]

40. Mbow, C.; Smith, P.; Skole, D.; Duguma, L.; Bustamante, M. Achieving mitigation and adaptation to climate change through sustainable agroforestry practices in Africa. Current Opin. Environ. Sust. 2014, 6, 8-14. [CrossRef]

41. International Resources Group. Management Plans for Lawachara National Park. Available online: http:/ / pdf.usaid.gov/pdf_docs/pnaed164.pdf (accessed on 30 November 2015). 
42. Mollah, A.R.; Nath, S.K.; Rahman, M.A.; Mannan, M.A. Secondary Data Collection for Pilot Protected Areas: Lawachara National Park; Nature Conservation Management (NACOM): Dhaka, Bangladesh, 2003.

43. Ahsan, M.F. Socio-ecology of the Hoolock Gibbon (Hylobateshoolock) in two forests of Bangladesh. Field Res. 2000, 12, 284-299.

44. Zar, J.H. Biostatistical Analysis. Available online: http://trove.nla.gov.au/work/7899770 (accessed on 30 November 2015).

45. Byg, A.; Salick, J. Local perspectives on a global phenomenonÍclimate change in Eastern Tibetan villages. Glob. Environ. Change 2008, 19, 156-166. [CrossRef]

46. Mertz, O.; Mbow, C.; Reenberg, A.; Diouf, A. Farmers' perceptions of climate change and adaptation strategies in rural Sahel. Environ. Manag. 2009, 43, 804-816. [CrossRef] [PubMed]

47. Apata, T.G. Factors influencing the perception and choice of adaptation measures to climate change among farmers in Nigeria. Evidence from farm households in southwest Nigeria. Environ. Econ. 2011, 2, 74-83.

48. Hageback, J.; Sundberg, J.; Ostwald, M.; Chen, D.; Yun, X.; Knutsson, P. Climate variability and land-use change in Danangou watershed, China-Examples of small-scale farmers' adaptation. Clim. Change 2005, 72, 189-212. [CrossRef]

49. Cabrera, V.E.; Breuer, N.E.; Hildebrand, P.E. North Florida dairy farmer perceptions toward the use of seasonal climate forecast technology. Clim. Change 2006, 78, 479-491. [CrossRef]

50. Thomas, D.S.G.; Twyman, C.; Osbahr, H.; Hewitson, B. Adaptation to climate change and variability: Farmer responses to intra-seasonal precipitation trends in South Africa. Clim. Change 2007, 83, 301-322. [CrossRef]

51. Shrestha, U.B.; Gautam, S.; Bawa, K.S. Widespread climate change in the Himalayas and associated changes in local ecosystems. PLoS ONE 2012, 7, e36741. [CrossRef] [PubMed]

52. International Union for Conservation of Nature (IUCN). Indigenous and Traditional Peoples and Climate Change. Available online: https://cmsdata.iucn.org/downloads/indigenous_peoples_climate_change.pdf (accessed on 30 November 2015).

53. Boykoff, M.T. Lost in translation? United States television news coverage of anthropogenic climate change 1995-2004. Clim. Change 2008, 86, 1-11.

54. Patt, A.G.; Schröter, D. Perceptions of climate risk in Mozambique: Implications for the success of adaptation strategies. Glob. Environ. Change 2008, 18, 458-467. [CrossRef]

55. Van Aalst, M.K.; Cannon, T.; Burton, I. Community level adaptation to climate change: The potential role of participatory community risk assessment. Glob. Environ. Change 2008, 18, 165-179. [CrossRef]

56. Alessa, L.; Kliskey, A.; Williams, P.; Barton, M. Perception of change in freshwater in remote resource-dependent Arctic communities. Glob. Environ. Change 2008, 18, 153-164. [CrossRef]

57. Laidler, G.J. Inuit and scientific perspectives on the relationship between sea ice and climate change: The ideal complement? Clim. Change 2006, 78, 407-444. [CrossRef]

58. Danielsen, F.; Burgess, N.D.; Balmford, A. Monitoring matters: Examining the potential of locally-based approaches. Biodivers. Conserv. 2005, 14, 2507-2542.

59. Rosenzweig, C.; Iglesias, A.; Yang, X.B.; Epstein, P.R.; Chivian, E. Climate change and extreme weather events: Implications for food production, plant diseases, and pests. Glob. Change Hum. Heal. 2002, 2, 90-104. [CrossRef]

60. Pautasso, M.; Döring, T.F.; Garbelotto, M.; Pellis, L.; Jeger, M.J. Impacts of climate change on plant diseases-opinions and trends. Europ. J. Plant. Pathol. 2012, 133, 295-313. [CrossRef]

61. Supit, I.; van Diepen, C.A.; de Wit, A.J.W.; Kabat, P.; Baruth, B.; Ludwig, F. Recent changes in the climatic yield potential of various crops in Europe. Agri. Syst. 2010, 103, 683-694. [CrossRef]

62. Chhetri, N.B.; Easterling, W.E. Adapting to climate change: Retrospective analysis of climate technology interaction in the rice-based farming system of Nepal. Ann. Assoc. Amer. Geogr. 2010, 100, 1-21. [CrossRef]

63. Patz, J.A.; Campbell-Lendrum, D.; Holloway, T.; Foley, J.A. Impact of regional climate change on human health. Nature 2005, 438, 310-317. [CrossRef] [PubMed]

64. Cruz, A. Holistic Adaptation Needed for Smallholders in the Philippines. Agroforestry World Blog, 2015. Available online: http://blog.worldagroforestry.org/index.php/2015/12/17/ (accessed on 17 December 2015).

65. Xu, J.C.; Sharma, R.; Fang, J.; Xu, Y.F. Critical linkages between land use transition and human health in the Himalayan region. Environ. Int. 2008, 34, 239-247. [CrossRef] [PubMed] 
66. Xu, J.C.; Yang, Y.; Li, Z.Q.; Tashi, N.; Sharma, R.; Fang, J. Understanding land use, livelihood and health transition of Tibetan nomads: A case from Gangga Township, Dingri County, TAR of China. EcoHealth 2008, 5, 104-114. [CrossRef] [PubMed]

67. Sharma, R. Impacts on Human Health of Climate and Land Use Change in the Hindu Kush-Himalayan Region: Overview of Available Information and Research Agenda. Mount. Res. Develop. 2012, 32, 480-486. [CrossRef]

68. Gunter, B.G.; Rahman, A.; Rahman, A.F.M.A. How Vulnerable are Bangladesh's Indigenous People to Climate Change?; Bangladesh Development Research Center: Virginia, USA, 2008.

69. Climate Change Cell Department of Environment. Climate Change and Health Impacts in Bangladesh; Climate Change Cell Department of Environment: Dhaka, Bangladesh, 2009.

70. Berkes, F.; Turner, N.J. Knowledge, learning and the evolution of conservation practice for social-ecological system resilience. Hum. Ecol. 2006, 34, 479-494. [CrossRef]

71. ICIMOD. Rural Livelihoods and Adaptation to Climate Change in the Himalayas; ICIMOD: Kathmandu, Nepal, 2010.

72. Ishaya, S.; Abaje, I.B. Indigenous people's perception on climate change and adaptation strategies in Jema'a local government area of Kaduna State, Nigeria. J. Geog. Reg. Plann. 2008, 1, 138-143.

73. Hassan, R.M.; Nhemachena, C. Determinants of climate adaptation strategies of African farmers: Multinomial choice analysis. Afr. J. Agri. Resou. Econ. 2008, 2, 83-104.

74. Thomson, A.M.; Calvina, K.V.; Chini, L.P.; Hurtta, G.; Edmonds, J.A.; Bond-Lamberty, B.; Frolking, S.; Wise, M.A.; Janetos, A.C. Climate mitigation and the future of tropical landscapes. Proc. Natl. Acad. Sci. USA 2010, 107, 19633-19638. [CrossRef] [PubMed]

75. PAR. The Use of Agrobiodiversity by Indigenous and Traditional Agricultural Communities in: Adapting to Climate Change; SPlatform for Agrobiodiversity Research, Biodiversity International: Rome, Italy, 2010.

76. Osman-Elasha, B. Human Resilience to Climate Change: Lessons for Eastern and Northern Africa; A final Report of AIACC Project No. AF 14; International START Secretariat: Washington DC, USA, 2006.

77. Barbier, B.; Yacouba, H.; Karambiri, H.; Zoromé, M.; Somé, B. Human vulnerability to climate variability in the Sahel: Farmers' adaptation strategies in northern Burkina Faso. Environ. Manag. 2009, 43, 790-803. [CrossRef] [PubMed]

78. Ramakrishnan, P.S. Traditional forest knowledge and sustainable forestry: A north-east India perspective. For. Ecol. Manag. 2007, 249, 91-99. [CrossRef]

79. Adger, W.N.; Huq, S.; Brown, K.; Conway, D.; Hulme, M. Adaptation to climate change in the developing world. Prog. Develop. Studies 2003, 3, 179-195. 